\title{
Investment as a factor of economic security of the region
}

\author{
Dmitri Loginov ${ }^{1}$ and Elena Karanina ${ }^{1, *}$ \\ ${ }^{1}$ Vyatka state University, Kirov, Russia
}

\begin{abstract}
Investment in the economy determines the effectiveness of economic security. Currently, insufficient attention is paid to assessing the impact of investment processes on the formation of economic security in the region. The results of the study show that the uneven investment processes in different regions of the Volga Federal district may indicate a different level of economic security of individual regions. The authors of the study propose to improve the state investment policy of regional governments in the direction of increasing the contribution of investment processes to the economic security of the region.
\end{abstract}

\section{Introduction}

Investment processes largely determine the state of the region's economy. The slowdown in the rate of investment in the economy affects the pace of economic growth in the most negative way.

The lack of investment in the regional economy may result in a future slowdown in the economic development of the region, as well as the strengthening of inter-sectoral structural imbalances in the regional economy. Investment processes should be considered not so much as a set of uncontrollable factors, but as an important instrument of influence on strengthening the economic security of the region.

Indeed, the growth in fixed capital investment may indicate that investment projects are actively implemented in the region, as a result of which new production assets will appear in the future and the region's economy will be replenished with new goods and services. Therefore, it is advisable to strengthen regional economic security by stimulating investment. Moreover, the financial condition of the region determines its investment attractiveness. Here, the readiness of the region to accept Federal funding within the framework of the implementation of state programs, as well as to be a suitable platform for the implementation of investment projects in the private sector of the economy are important.

The working hypothesis of the present study is the assumption that under the influence of the acceleration of the growth rate of investment in fixed capital, it is possible to strengthen the economic security of the region. Accordingly, such activities should be the

\footnotetext{
*Corresponding author: karanina@vyatsu.ru
} 
subject of close attention by regional governments, and the promotion of investment processes should be among the main instruments of economic growth in the region.

\section{Materials and Methods}

The study is based on such materials as the results of generalization of researchers ' works in the field of influence of investment processes on the economic security of the region, as well as on the assessment of quantitative indicators characterizing investment processes in the region in the long-term retrospective, which allows to assess the dynamics of investment processes in fixed assets in the regional economy and, accordingly, to draw a conclusion about the degree of success of investment policy as an aspect of activities to ensure the economic security of the region. The main methods of research are monographic, generalization of the results of research carried out earlier, assessment of growth rates of indicators of investment development of the region in the long-term retrospective, own observations of the authors, as well as the comparative method of research and the method of socio-economic design. The authors conducted a quantitative assessment of the levels of investment in fixed capital of the regions of the Volga Federal district for 2005-2017 and calculated the growth rate of this indicator in absolute terms for 2017 relative to 2005 . The assessment was carried out in comparison with the values of investments in fixed assets made in the whole of the Russian Federation and the Volga Federal district for the same period of time.

The inflow of investments into the economy of the region is a condition for the security of the economic development of the territory. This is due to the role of investment in the formation of investment attractiveness of the region [6, P.82].

The active role of investments in the formation of economic security of both the territory and the country as a whole is considered. In particular, the influence of investments on strengthening food security is revealed [1, P.59].

The role of investments in the economic security of the region is also analyzed in terms of their impact on the environmental performance of the industry. It is shown that the growth of investment attractiveness of the region provides an increase in the inflow of modern, economically safe industrial areas, which, in turn, makes the economy of the region more stable and protected [14, P.96].

There is also an alternative point of view, according to which the economic security of the region can be ensured not by quantitative increase of investments, but by increasing the use of modern information technologies in the production of goods, which reduces the cost of organizing new industries, and therefore makes the economy more efficient and sustainable [10, P.79].

An interesting position is that the acceleration of economic development of the region should be based on the democratization of capital, that is, improving the security of investment, protection of property rights and the creation of preferences for investment by small and medium-sized businesses. According to the authors of this approach, the democratization of capital can significantly increase the flow of investment in the economy of the region, and therefore, by accelerating economic growth to lead the economic security of the territory to higher values [4, P.416].

There are studies proving the existence of a direct link between the volume of investment in the economy of the territory and the pace of economic development. It is proposed to increase investment in the economy of the region through the active use of the technique of creation of territories of priority development with the simultaneous elimination of their tactical deficiencies identified during the initial stages of their formation [2, P.238]. 
It is widely believed that the investment security of the region provides an improvement of the investment climate and the factor of reducing investment risks. It is proposed to use investment security as one of the key factors of economic security of the region, when the emphasis on investment security contributes to the renewal of capital in the leading sectors of the economy and reduce the imbalance in the economic development of individual regions [13, P.69].

A utilitarian approach to assessing the role of investments in ensuring the economic security of the region is not excluded. In particular, it is shown that the activation of investment processes in a particular industry and the transition to modern methods of assessing the effectiveness of investment can improve the efficiency of the resource potential of the region, thereby increasing the level of economic security of the territory [5, P.84].

The research touches upon the problem of investment susceptibility of the region's economy. It is noted that investment susceptibility is formed on the basis of the management of the investment climate of the territory, which in turn largely depends on the regional economic policy. By managing the investment attractiveness, including with the help of tools to support the participants of investment activities, the public authorities of the region can achieve a significant increase in the level of industrial and agricultural development of the regional economy and, accordingly, strengthen the economic security of the region [12, P.110].

It is emphasized that the regional economic policy to support the participants of investment activities should be considered, justified. This policy should be organized from the standpoint of ensuring the achievement of the final effect - attracting so much investment in a particular industry or the economy of the territory as a whole, in order to achieve a world level of competitiveness of products. In the opposite case, insufficient measures to support investment participants are ineffective and do not justify the costs incurred. Today it is necessary to bring regional economic policy and, above all, regional industrial and agricultural policy to a qualitatively higher level, characterized by a focus on the program-target principle of planning [15, P.125].

At the same time, it is extremely important to position the region as an object of investment in terms of its industry specialization. The role of investments in the economic security of the region is proposed to be considered through the prism of providing innovative processes with the necessary financial resources, which requires a deep rethinking of approaches to attracting investments in the regional economy. It is advisable to conduct a state regional policy to support investment processes in close integration with the innovation strategy of the region, when investments become targeted, ensuring the achievement of innovative goals in various areas of specialization of the regional economy [8, P.22].

It is also important to ensure the effective functioning of small businesses using the tools of regional economic policy as a means of ensuring the investment security of the region. It is especially important to carry out an active policy to promote investment activities of small businesses in areas with a monostructure of the economy, for example, in single-industry towns [7, P.254].

An interesting point of view is that one of the important economic results of improving investment security at the micro level is to reduce the tax costs of the organization. On the regional scale, targeted state support for investment activities could provide a massive effect of reducing the tax burden, and thus increase the investment attractiveness of the regional economy as a whole, and the growth of the overall economic security of the territory [11, P.110].

The impact of investments on the economic security of the region is also considered from the point of view of investment potential management. Influencing the processes of 
using the investment potential of the region, it is possible to achieve a significant increase in investment in the regional economy, thereby ensuring the implementation of the principle of sustainable development in the management of socio-economic development of the region [9, P.393].

An important aspect of regional investment security policy is the implementation of measures to stimulate investment in human capital. Indeed, the quality of human resources is a prerequisite for successful economic development. Given the importance of public spending in investing in human capital, considerable attention should be paid to the quality of social policy in ensuring the economic security of the region [3, P.63].

Thus, the studies of various authors emphasize various aspects of the role of investment in ensuring the economic security of the region. However, the key factor of influence of investment processes on strengthening and development of regional economic security is not revealed.

\section{Results}

According to the authors of the study, the role of investment in the economic security of the region is determined by such aspects as: 1) the resource of financing economic growth; 2) the factor of increasing labor productivity in the economy; 3) the means of activation of innovative processes and the introduction of innovative technologies in industry and agriculture; 4) the condition of accelerating economic growth of the regional economy; 5) the prerequisite for improving the quality of human potential of the region.

According to the authors, the role of investment in ensuring the economic security of the region is still underestimated, due to the focus on certain aspects of economic security, not so much macroeconomic as sectoral. This approach should be reviewed and the focus should be on macroeconomic factors to strengthen the economic security of the region.

According to the information presented in the table, the volume of investments in fixed assets in Russia as a whole for 2017 exceeded 16 trillion rubles. This is 4.4 times more than in 2005. It is important to note that with the exception of 2009 and 2015, the absolute level of investment in the country did not decrease compared to the previous year. In 2009, the volume of investments decreased by 9.1 percent, and in 2015 - by 0.3 percent compared to the previous year. In both cases, it is impossible to speak of any catastrophic drop in investment. These events are quite consistent with the picture of the impact of unfavorable global market conditions recorded in the considered periods of time. Moreover, the decline was observed only in the previous year. If we compare the levels of 2009 and 2007, as well as 2015 and 2013, we can see that in each case the level of the new period was higher than that recorded two years earlier. This suggests that the process of investment growth was only slightly out of the usual trend, but on the scale of the two-year alignment remained with a positive growth rate. This shows that the Russian economy is growing steadily.

Table 1. Investments in fixed capital, in actual prices, million rubles

\begin{tabular}{|c|c|c|c|c|c|c|c|c|c|c|c|c|c|c|}
\hline Territory & 2005 & 2006 & 2007 & 2008 & 2009 & 2010 & 2011 & 2012 & 2013 & 2014 & 2015 & 2016 & 2017 & $\begin{array}{c}\text { Growth } \\
\text { rate of } \\
\text { the } \\
\text { indicat } \\
\text { or } \\
(2017 \\
\text { to } \\
2005), \\
\% \\
\end{array}$ \\
\hline Russi & 361110 & 473002 & 671622 & 878161 & 797601 & 915209 & 110356 & 125860 & 134502 & 139026 & 138971 & 147488 & 160273 & 443,8 \\
\hline Federation & & 3 & 2 & 6 & 3 & 6 & 52 & 90 & 38 & 45 & 87 & 46 & 02 & \\
\hline $\begin{array}{l}\text { Volga } \\
\text { federal } \\
\text { district }\end{array}$ & 609499 & 783640 & $\begin{array}{r}114839 \\
6\end{array}$ & $\begin{array}{r}148534 \\
1\end{array}$ & $\begin{array}{r}127915 \\
4 \\
\end{array}$ & $\begin{array}{r}143747 \\
2\end{array}$ & $\begin{array}{r}170252 \\
0\end{array}$ & $\begin{array}{r}201287 \\
6\end{array}$ & $\begin{array}{r}230129 \\
8\end{array}$ & $\begin{array}{r}238434 \\
9\end{array}$ & $\begin{array}{r}246334 \\
6\end{array}$ & $\begin{array}{r}243808 \\
1\end{array}$ & $\begin{array}{r}242883 \\
5\end{array}$ & 398,5 \\
\hline Republic of & 84471 & 107751 & 160345 & 203657 & 148142 & 153625 & 188506 & 233683 & 266395 & 283544 & 317764 & 355109 & 278591 & 329,8 \\
\hline
\end{tabular}




\begin{tabular}{|l|c|c|c|c|c|c|c|c|c|c|c|c|c|c|}
\hline $\begin{array}{l}\text { Bashkortost } \\
\text { an }\end{array}$ & & & & & & & & & & & & & \\
\hline $\begin{array}{l}\text { The } \\
\text { Republic Of } \\
\text { Mari El }\end{array}$ & 7722 & 10691 & 17204 & 21408 & 16576 & 22304 & 26860 & 31656 & 46177 & 47228 & 40331 & 27265 & 24029 & 311,2 \\
\hline $\begin{array}{l}\text { Republic of } \\
\text { Mordovia }\end{array}$ & 15123 & 19597 & 27414 & 39254 & 31968 & 40778 & 48672 & 49824 & 53713 & 47484 & 52750 & 52629 & 58535 & 387,0 \\
\hline $\begin{array}{l}\text { Republic of } \\
\text { Tatarstan }\end{array}$ & 139361 & 160605 & 214557 & 273098 & 277573 & 328943 & 393568 & 470751 & 525730 & 542781 & 617128 & 636494 & 637611 & 457,5 \\
\hline $\begin{array}{l}\text { Udmurt } \\
\text { Republic }\end{array}$ & 26876 & 34311 & 44565 & 53536 & 40450 & 51148 & 62311 & 64220 & 82678 & 91571 & 81846 & 87128 & 83705 & 311,4 \\
\hline $\begin{array}{l}\text { Chuvash } \\
\text { Republic }\end{array}$ & 19445 & 25860 & 38069 & 50473 & 35688 & 42611 & 55924 & 65254 & 60121 & 53457 & 55725 & 50139 & 52365 & 269,3 \\
\hline $\begin{array}{l}\text { Perm region } \\
\text { Kirov } \\
\text { region }\end{array}$ & 17080 & 75519 & 122480 & 152363 & 132274 & 139652 & 144781 & 162241 & 219493 & 207597 & 226213 & 239389 & 245139 & 431,6 \\
\hline $\begin{array}{l}\text { Nizhny } \\
\text { Novgorod } \\
\text { region }\end{array}$ & 64581 & 89272 & 133188 & 207392 & 201692 & 192072 & 224350 & 257454 & 280884 & 276819 & 235066 & 232010 & 245268 & 379,8 \\
\hline $\begin{array}{l}\text { Orenburg } \\
\text { region }\end{array}$ & 39993 & 52952 & 80352 & 108868 & 91268 & 103648 & 116657 & 151250 & 152876 & 153978 & 169243 & 167278 & 184877 & 462,3 \\
\hline $\begin{array}{l}\text { Penza } \\
\text { region }\end{array}$ & 15689 & 25459 & 44023 & 52632 & 43603 & 45677 & 57495 & 72342 & 82164 & 82079 & 89042 & 64945 & 72050 & 478,4 \\
\hline $\begin{array}{l}\text { Samara } \\
\text { region }\end{array}$ & 67206 & 88559 & 137126 & 148262 & 111189 & 154422 & 182575 & 213021 & 269736 & 321759 & 302884 & 256775 & 259544 & 386,2 \\
\hline $\begin{array}{l}\text { Saratov } \\
\text { region }\end{array}$ & 40435 & 46992 & 56709 & 83221 & 67760 & 80040 & 101406 & 117645 & 125833 & 137421 & 140128 & 141337 & 145163 & 359,0 \\
\hline $\begin{array}{l}\text { Ulyanovsk } \\
\text { region }\end{array}$ & 14711 & 21881 & 34970 & 48507 & 49500 & 47993 & 59225 & 72984 & 76835 & 77178 & 79461 & 70575 & 84093 & 571,6 \\
\hline
\end{tabular}

Source: Federal state statistics service

During the same time, the volume of annual investments in fixed capital of the Volga Federal district increased by 4.0 times. This growth rate generally corresponds to what is observed in Russia as a whole, but slightly lower than it, which indicates the presence of unresolved problems in industrial development, given that the Volga Federal district specializes in manufacturing industries. Obviously, it is necessary to strengthen the policy of supporting investment in the manufacturing industry to ensure the rapid growth of investment in the economy is due to the investment development of manufacturing industries. It is noteworthy that in 2009 the volume of investments in the economy of the Volga Federal district regions decreased to the level of the previous year, repeating the trend at the level of Russia as a whole. However, the depth of the fall was higher-by 13.9 percent. This may indicate that the manufacturing industry was more sensitive to the factors of the global economic crisis that developed in 2008-2009. However, just as in Russia as a whole, the level of investment decline in 2009 in the Volga Federal district was outlined only to the level of the previous year, but the absolute value of this indicator was higher than the level of 2007, which indicates a relatively adequate response of investors to the deterioration of the economic situation.

Nevertheless, in 2015 and subsequent years, the picture of investment in the economy of the Volga Federal district regions differed from the trends in Russia as a whole. In particular, in 2015, there was no decrease in the volume of investments at the level of the Volga Federal district, in contrast to the national level. However, in 2016 and 2017 there was a trend of systematic decline in the level of annual investments in fixed assets. So in 2016, the analyzed indicator for the Volga Federal district decreased by 1.0 percent compared to the previous year. In 2017, the process continued, and the absolute value of investments in fixed assets in the district fell by 0.4 percent. This fact suggests that the potential for investment in the economy of the Volga Federal district regions could be significantly affected in recent years, which requires the activation of the state policy of attracting investment in the economy of the Volga regions of Russia.

The growth rate of investment in fixed assets in some regions of the Volga Federal district was very different in the study period. Thus, the maximum growth rate of the analyzed indicator was recorded in the Ulyanovsk region, it was 571.6 percent. High values 
of the indicator were also noted in the Penza and Orenburg regions, as well as in the Republic of Tatarstan. The most insignificant growth rate of investments in fixed assets for the analyzed period was observed in the Chuvash Republic. The level of this index amounted to only 269.3 percent. Also low was the estimated figure in the Udmurt Republic, the Republic of Mari El, the Republic of Bashkortostan and the Kirov region.

\section{Discussion}

The authors of the study believe that the importance of investment in the economic security of the region is still underestimated. It is fair to conclude that investments determine the nature of economic growth in the region and lay the Foundation for its future economic security.

The authors of this article propose to clarify the role of investment in the economic security of the region and identify the following areas of influence of investment on the level of economic security: 1) the impact of investment on the diversification of the region's economy; 2) the impact of investments on increasing the level of innovation in the regional economy; 3) the impact of investments on the growth of the share of the private sector in the economy of the region; 4) the impact of investments on scientific and technological progress in the region.

\section{Conclusions}

When developing measures to ensure the economic security of the region, special attention should be paid to the effectiveness of the investment strategy of the region. Stimulation of investment processes helps to accelerate the growth of value added within the borders of the region, and therefore ultimately allows to accelerate the growth rate of the regional economy.

The rate of growth of fixed investment in the long term is very different between regions, which may be due to differences in the results of regional governments ' economic policies.

The state should develop new approaches to stimulating investment processes at the regional level and strengthen the monitoring of economic security through the analysis of indicators of investment processes.

\section{References}

1. V. E. Afonina, Addressing the issue of ensuring food security of the country at the expense of investment and innovation potential (Economy and entrepreneurship), 42(45), pp 57-60 (2013)

2. V. P. Chichkanov, L. A. Belyaevskaya-Plotnik, Territories of advanced development in the context of economic security of the macroregion (Regional economy), T.14, 1. pp. 227-242 (2018)

3. E. N. Dubrovina, Analysis of the impact of social factors on the economic security of the region (on the example of the Vladimir region) (National interests: priorities and security), T.11, 8(293), pp. 58-66 (2015)

4. A. A. Galkin, J. A. Salikov, J. N. Slepchenko, Strategic directions of social management of the Voronezh region economy (Bulletin of Voronezh state University of engineering technologies), T.80, 1(75), pp 413-418 (2018) 
5. L. P. Goncharenko, S. A. Sybachin, E. R. Sharko, Application of innovative production technologies at the enterprises of the woodworking industry of Russia (Theoretical and applied Economics), 3, pp. 70-87 (2018)

6. O. V. Fedonina, Investment security as a key factor of sustainable development of the Russian Federation and the Republic of Mordovia (Online journal "Science"), T.8, 2(33), p. 82 (2016)

7. E. V. Karanina, O. A. Ryazanova, Conceptual approach to assessing the investment security of the territory from the perspective of creditworthiness risks of small businesses (on the example of single-industry towns of the Kirov region) (Innovative economic development), 4(40), pp. 250-259 (2017)

8. S. A. Lipina, O. L. Smirnova, Innovation as a driver of safe economic growth of macro-and meso-levels of the national economic system (Regional economy. South of Russia), 4(18), p. 16-27 (2017)

9. E. V. Nikulina, M. A. Gayvoronskaya, E. A. Dynnikov, A. V. Orlova, Identification of" growth points " of the region as the basis of economic security and sustainable investment development (Fundamental study), 2-12, pp. 390-395 (2015)

10. P. I. Ogorodnikov, E. P. Guseva, Increase of economic security on the basis of information support of innovative economy functioning (Scientist's notes), 6(31), pp. 75-81 (2018)

11. V. G. Pavlov, D. V. Pavlov, Formalization of the tax optimization model in solving the problem of investment in the conditions of existing economic sanctions (Economics and business: theory and practice), 3, pp. 107-112 (2016)

12. E. S. Pereverzeva, A. M. Kulik, E. I. Makrinova, I. J. Kapustina, Analysis of threats to investment security and indicators of investment activity of the Belgorod region (Fundamental study), 4, pp. 109-114 (2018)

13. O. N. Pechertseva, Investment and food security in the region (Agri-food policy of Russia), 6(42), pp. 67-70 (2015)

14. G. A. Reznik, A. A. Malyshev, Ecologization of production of the Penza region (Problems of social and economic stability of the region. Collection of articles VIII International scientific-practical conference. Penza state University of architecture and construction, University of Dodoma (Tanzania), pp. 92-98 (Penza, 27-28 January 2016)

15. A. N. Sheglova, J. N. Babak, E. V. Bykadorova, Development of investment and innovation model of agricultural production in the region (Bulletin of don state agrarian University), 3-1(21), pp. 120-127 (2016) 